\title{
DEVELOPMENT OF AN AUTOMATIC SAMPLING UNIT FOR MEASURING RADIOCARBON CONTENT OF GROUNDWATER
}

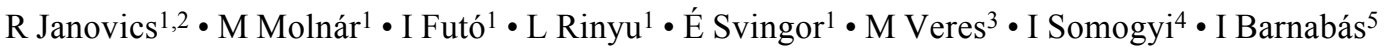

ABSTRACT. An automatic water sampling unit was developed to monitor the radioactive emission (radiocarbon and other corrosion and fission products) from nuclear facilities into the groundwater. Automatic sampling is based on the principal of ion exchange using built-in resin columns in the submerging samplers. In this way, even the short-term emissions can be detected. According to our experiments, the ${ }^{14} \mathrm{C}$ activity concentrations and the $\delta^{13} \mathrm{C}$ values of the samples made by the ion exchange method are systematically underestimated compared to the real values. The carbonate adsorption feature of the sampling unit was studied under laboratory and field conditions. For this purpose, a test method was developed. The observed sampling efficiencies and additionally some carbon contamination for the sampling method itself have to be taken into consideration when we estimate the amount of ${ }^{14} \mathrm{C}$ contamination introduced into the groundwater from a nuclear facility. Therefore, a correction factor should be made for the ${ }^{14} \mathrm{C}$ anion exchange sampling. With the help of this correction, the results converge to the expected value.

\section{INTRODUCTION}

In the monitoring of environmental loads from nuclear facilities, the role of groundwater is especially important due to its natural presence, biological role, rapid movement in the geosphere, and its reactive and solvent nature. Thus, sampling and monitoring of the radionuclide content of groundwater is one of the most prominent tasks in environmental control (Vrba 1988).

One of the most widespread approaches to control the areas of radioactive contamination is extensive isotope-analytical measurement of the groundwater in the affected area (Eggers 1976; Stow and Haase 1986; Hart and Spruill 1988; Mulsow et al. 1999). The simplest procedures can be used only for occasional sampling, and these illustrate the conditions at that given moment. In the course of these methods, 3-5 samples are taken from the monitoring well. A certain indicator parameter is monitored continuously until it becomes constant, at which point a sample is taken (Hazardous Waste Bureau 2001). In many cases, short-interval emissions cannot be monitored with these techniques.

Taking integrated samples seems to be more efficient, confident, and cheaper than measurement of the conditions at a given time. Numerous methods for this purpose are reported in the literature (e.g. King 1993). Simpler samplers with plastic membranes based on diffusion have been used to take gas, dissolved inorganic or organic compounds, and even groundwater bacteria samples (Ronen et al. 1987; Karp 1993; de Jonge and Rothenberg 2005; Divine et al. 2005; Petruzzi and Silliman 2006; Spalding and Watson 2007).

There were considerable efforts to enable automatic and more cost-effective sampling methods (Granato and Smith 1999; Jones et al. 1999). The Institute of Nuclear Research of the Hungarian Academy of Sciences (MTA ATOMKI) is developing a groundwater sampling system able to take integrated samples. The sampler consists of 3 main parts (Figure 1). The groundwater is collected in the sampling unit through a cotton filter. The second part of the device contains a control unit, a

\footnotetext{
${ }^{1}$ Hertelendi Laboratory of Environmental Studies, MTA ATOMKI, Debrecen, Hungary.

${ }^{2}$ Corresponding author. Email: janovics@atomki.hu.

${ }^{3}$ Isotoptech Zrt, Debrecen, Hungary.

${ }^{4}$ Iontech Kft, Litér, Hungary.

${ }^{5}$ Public Agency for Radioactive Waste Management (PURAM) of Hungary, Budaörs, Hungary.
}

(C) 2010 by the Arizona Board of Regents on behalf of the University of Arizona Proceedings of the 20th International Radiocarbon Conference, edited by A J T Jull RADIOCARBON, Vol 52, Nr 2-3, 2010, p 1141-1149 
pump, a flow-meter, and batteries. The third part includes ion exchange resin columns. Two cation exchange columns and 1 anion-exchange column are in serial connection $(50 \mathrm{~cm}$ length and $44 \mathrm{~mm}$ ID each column). The effluent from resins is carried by a spiral pipe out of the well.

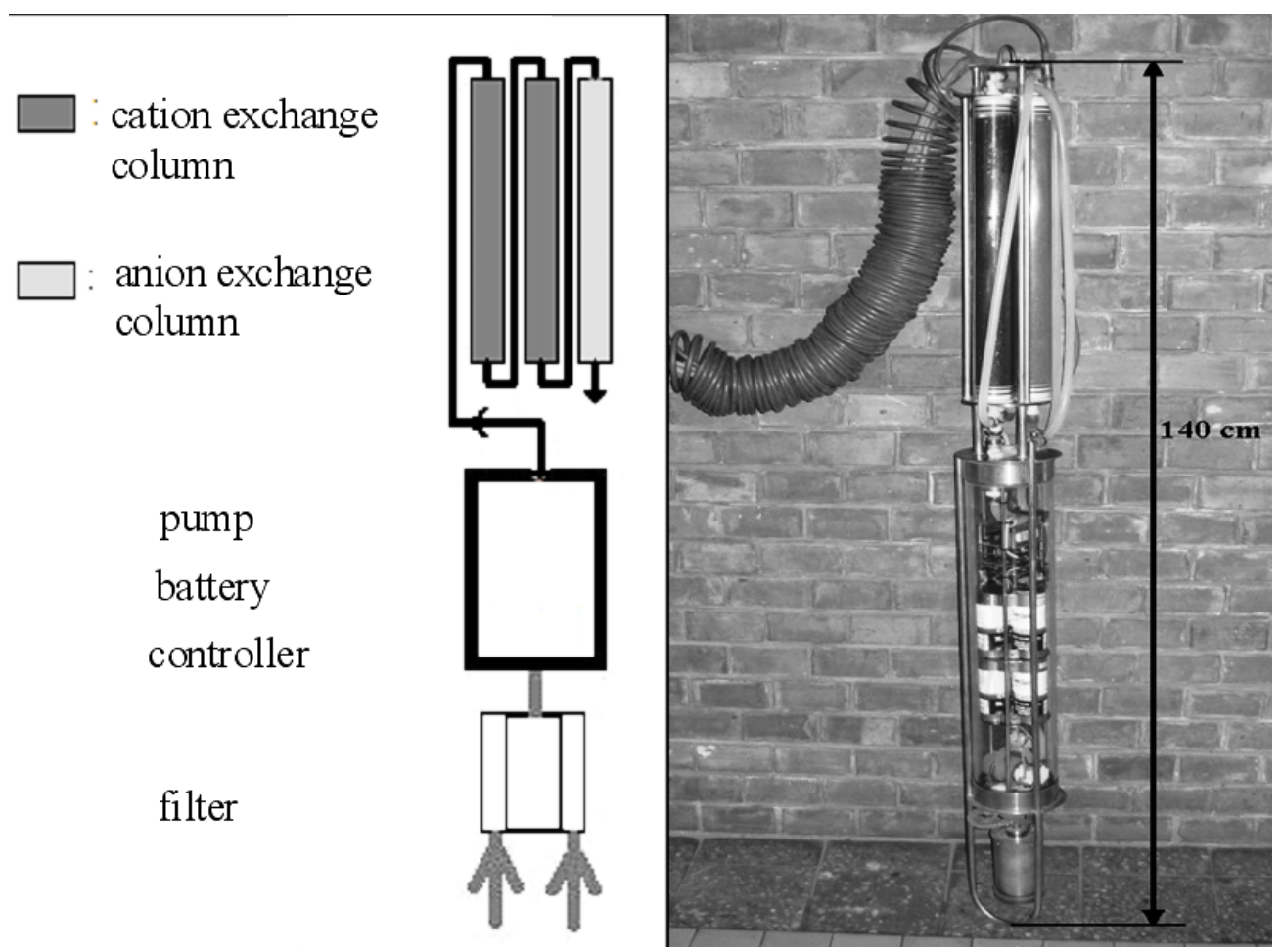

Figure 1 Automatic groundwater sampling unit

To control the release of radioactive isotopes, ${ }^{14} \mathrm{C}$ automatic samplers were installed in several observation wells near some Hungarian nuclear facilities (Püspökszilágy Radioactive Waste Disposal Facility and Paks nuclear power plant). The automatic sampling unit is able to take groundwater samples continuously, while the conventional ${ }^{14} \mathrm{C}$ sampling method (based on barium-chloride precipitation) can only be used for ad hoc sampling. In this way, even short emissions could be detected.

The automatic samplers contain columns filled with cation and anion exchange resin. The sampler works $2 \mathrm{~m}$ below the groundwater level with the help of water pumps. After a 2-month working period, the trapped ions are eluted from the resins. The activity of the gamma-emitters, ${ }^{14} \mathrm{C},{ }^{90} \mathrm{Sr}$, and transuranium elements are measured from the eluate. The anion exchange resin exchanges the dissolved $\mathrm{HCO}_{3}{ }^{-}$ions for $\mathrm{OH}^{-}$ions. The ${ }^{14} \mathrm{C}$ content of the dissolved $\mathrm{HCO}_{3}{ }^{-}$eluted from the resin is determined by conventional beta counting (gas proportional counting or liquid scintillation counting).

\section{EXPERIMENTAL}

In the course of normal laboratory experiments, the adsorption conditions of ion exchange resins are standard, and the sample solutions flow by an optimally set constant rate through the ion exchange columns. Those processes are relatively short; therefore, the ion migration due to diffusion has only a negligible influence on the ion exchange capacity. However, the whole sampling interval by our automatic sampling unit could be 2 months, and there is still water above the resin for a significant 
part of this time. During this period, the ions already adsorbed onto the resin may migrate through the whole volume of the resin by ion diffusion. This phenomenon could decrease the efficiency of the ion exchange resins.

\section{Materials Used}

In the sampling units, we used Varian ${ }^{\circledR}$ AT-N, a strongly alkaline anion-exchange resin with quaternary ammonium active groups (changeable ion form: $\mathrm{OH}^{-}$, particle size: $315-1250 \mu \mathrm{m}$ ), and Varian KS-N, a strongly acidic cation-exchange resin with sulfo-active groups (changeable ion form: $\mathrm{H}^{+}$, particle size: $315-1250 \mu \mathrm{m}$; Nitrokémia Co.). The matrix of resins is styrene-divinylbenzene copolymer. All reagents used were of analytical grade $\left(\right.$ Scharlau $^{\circledR}$, Spektrum-3D ${ }^{\circledR}$, Merck $\left.^{\circledR}\right)$.

Groundwater from a real sampling area was used in the experiments as model water. It is of key importance to know the water chemistry parameters of the groundwater to determine the efficiency of the ion exchange resin. The conductivity and the $\mathrm{pH}$ of the groundwater were $980 \pm 43 \mu \mathrm{S}$ and 7.01, respectively. The elemental composition of the groundwater was measured by ICP-AES $\left(\right.$ Spectroflame $\left.{ }^{\circledR}\right)$. The material of the aquifer is loessic river drift; therefore, the groundwater contains mostly calcium-hydrocarbonate. Table 1 shows the concentrations of the 8 major ions (Maucha 1932) being characteristic of the halobity of waters.

Table 1 Concentration of major anions and cations in groundwater sample.

\begin{tabular}{ll|ll}
\hline Anions & $\left(\mathrm{mg} / \mathrm{dm}^{3}\right)$ & Cations & $\left(\mathrm{mg} / \mathrm{dm}^{3}\right)$ \\
\hline $\mathrm{HCO}_{3}{ }^{-}$ & $(4.28 \pm 0.21) \times 10^{2}$ & $\mathrm{Ca}^{2+}$ & $(1.82 \pm 0.07) \times 10^{2}$ \\
$\mathrm{SO}_{4}^{2-}$ & $(6.22 \pm 0.04) \times 10^{1}$ & $\mathrm{Mg}^{2+}$ & $(3.29 \pm 0.03) \times 10^{1}$ \\
$\mathrm{Cl}^{-}$ & $(2.51 \pm 0.02) \times 10^{1}$ & $\mathrm{Na}^{+}$ & $(1.78 \pm 0.01) \times 10^{1}$ \\
$\mathrm{CO}_{3}{ }^{2-}$ & $<2.1$ & $\mathrm{~K}^{+}$ & $1.80 \pm 0.02$ \\
\hline
\end{tabular}

\section{Model Test}

Model tests with groundwater from the sampling area were executed under controlled laboratory conditions similar to the natural ones, to determine to what extent the field conditions influence the characteristics of the sample taken. In order to keep the temperature of the sample similar to the average groundwater temperature, the tests were carried out in a cold $\left(15^{\circ} \mathrm{C}\right)$ room of the laboratory. In order to avoid mixing of the resin, the groundwater flows into the columns in every case from above. During the tests, a pump system controlled by a PC pushes $1 \mathrm{~L}$ of water through the resin columns every $30 \mathrm{~min}$ for $30 \mathrm{hr}$. Altogether, $60 \mathrm{~L}$ of water sample were treated. Two parallel resin units $(\mathrm{R} 1, \mathrm{R} 2)$ and a control line $(\mathrm{C})$ without resin were used in the test. During these 6-hr periods, $1.5 \mathrm{~L}$ of untreated water sample was taken for ${ }^{14} \mathrm{C}$ measurement from the control line (conventional reference method: based on barium-chloride precipitation). The $\mathrm{pH}$, conductivity, and temperature of these samples were also measured. The samples from the control line were treated by the conventional $\mathrm{BaCl}_{2}$ precipitation method typically used for ${ }^{14} \mathrm{C}$ measurements.

\section{Elution and $\mathrm{CO}_{2}$ Recovery}

After sampling, the anion-exchange resin columns are opened in a $\mathrm{CO}_{2}$-free manipulator box, and the resin is washed into the eluting column using high-purity distilled water. The adsorbed carbonate on the resins was eluted with $1300 \mathrm{~mL}$ of $10 \mathrm{M} \mathrm{NaNO}_{3}$ solution. The rate of elution was $10-12 \mathrm{~mL} /$ min. The $\mathrm{BaCO}_{3}$ sample taken by conventional methods and the $\mathrm{NaCO}_{3}$ taken by the automatic sampling unit were prepared for gas proportional counting. 


\section{Radiocarbon Measurement}

We measured the ${ }^{14} \mathrm{C}$ activity of the samples using a gas proportional counting (Csongor and Hertelendi 1986; Hertelendi et al. 1989). To extract $\mathrm{CO}_{2}$ from the samples, sulfuric acid was added to the $\mathrm{NaCO}_{3}$ solution. Prior to its measurement, the liberated $\mathrm{CO}_{2}$ gas was purified over charcoal, then frozen into a $\mathrm{CO}_{2}$ trap with liquid nitrogen at $-196{ }^{\circ} \mathrm{C}$, and the remaining non-condensable components were removed by a vacuum pump (Csongor et al. 1982). The standard deviation of a single $\Delta{ }^{14} \mathrm{C}$ measurement by this method was $4-5 \%$ after a 1-week-long measurement for each sample (Hertelendi 1990). The reported $\Delta^{14} \mathrm{C}$ data were corrected for decay and $\delta^{13} \mathrm{C}$ values measured by a

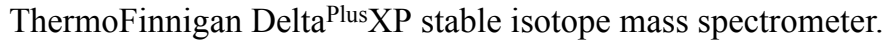

\section{RESULTS}

The amount of the $\mathrm{CO}_{2}$ collected and its ${ }^{14} \mathrm{C}$ activity concentration were measured after the recovery of carbonate samples taken by the automatic sampler and conventional barium-chloride precipitation. Differences were found between the results of the 2 methods in the amount of $\mathrm{CO}_{2}$, the $\delta^{13} \mathrm{C}$ value, and the ${ }^{14} \mathrm{C}$ activity concentration (Table 2 ).

Table 2 Results of ${ }^{14} \mathrm{C}$ measurements.

\begin{tabular}{llllll}
\hline Sample & $\begin{array}{l}\text { Water mass } \\
(\mathrm{kg})\end{array}$ & $\begin{array}{l}\mathrm{Gained} \mathrm{CO}_{2} \\
(\mathrm{~g} / \mathrm{L} \text { water })\end{array}$ & $\begin{array}{l}\text { Excess } \mathrm{CO}_{2} \text { compared to } \\
\text { the conventional method }\end{array}$ & $\begin{array}{l}\delta^{13} \mathrm{C}(\%) \\
\pm 0.2 \% 0\end{array}$ & $\begin{array}{l}{ }^{14} \mathrm{C}_{\mathrm{c}}(\mathrm{pMC}) \\
\pm 0.5 \mathrm{pMC}\end{array}$ \\
\hline $\mathrm{C}$ & 12.04 & 0.21 & - & -11.04 & 104.1 \\
$\mathrm{R} 1$ & 63.45 & 0.26 & $27 \%$ & -12.81 & 94.7 \\
$\mathrm{R} 2$ & 63.74 & 0.30 & $44 \%$ & -12.85 & 94.4 \\
\hline
\end{tabular}

a Sample $\mathrm{C}$ is a control sample taken by the conventional method. This sample was used as a reference.

The $\mathrm{CO}_{2}$ amount obtained from the ion exchange resin was always higher by $30-40 \%$ than for samples taken by the conventional method. However, the ${ }^{14} \mathrm{C}$ content of the carbonate dissolved from the resin was always $\sim 10 \%$ lower than the ${ }^{14} \mathrm{C}$ content of the barium carbonate precipitate. The $\delta^{13} \mathrm{C}$ value of the elute was $1.7 \%$ lower than the sample taken by the conventional method (Figure 3 ).

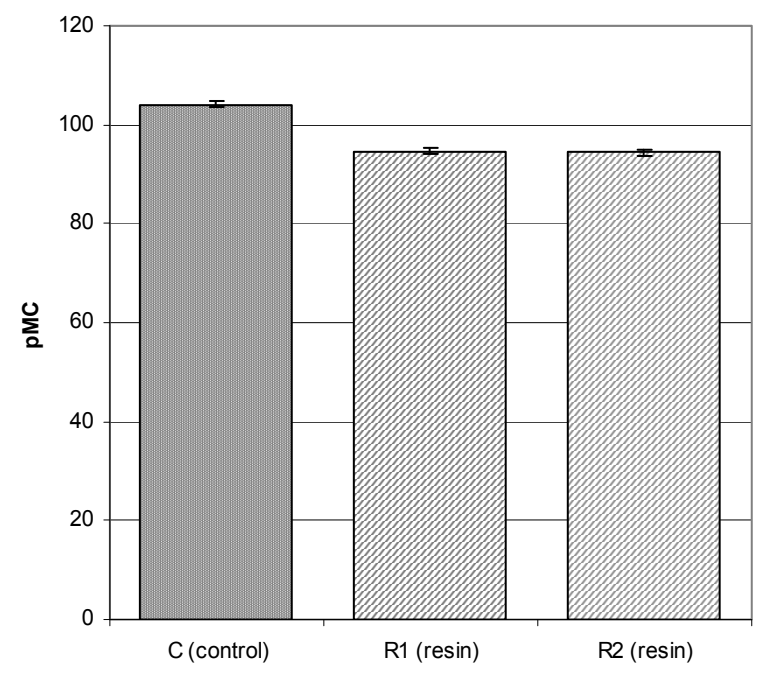

Figure 2 Comparison of ${ }^{14} \mathrm{C}$ activity concentration of the samples taken by the conventional and the automatic sampling method. 


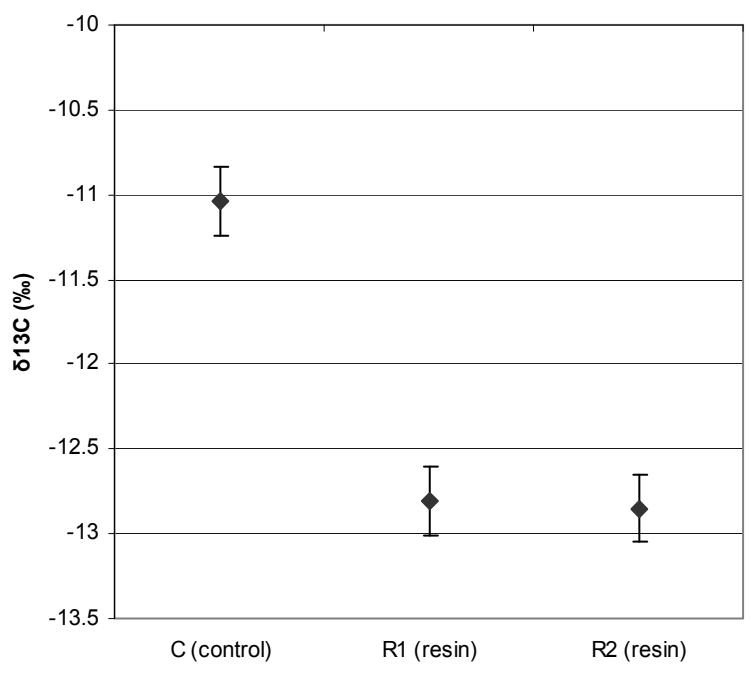

Figure 3 Comparison of $\delta^{13} \mathrm{C}$ values of samples taken by the conventional and the automatic sampling method.

\section{Phenomenon of Excess $\mathrm{CO}_{2}$ being Proportional to the Amount of the Resin}

It seems logical that the excess $\mathrm{CO}_{2}$ derives from resin or other materials from the applied elution process. The real efficiency of elution is unknown, as we have some additional unknown amount of carbon after the elution. The following hypotheses were made in the course of calculation. The elution efficiency for the $\mathrm{R} 2$ test was assumed to be about $100 \%$ because it produced the higher specific yield. On the basis of this, calculating with the material balance, we have found that $684 \mathrm{~cm}^{3}$ of resin gives $5.89 \mathrm{~g}$ of excess $\mathrm{CO}_{2}$ (Table 3 ).

Table 3 Excess $\mathrm{CO}_{2}$ proportional to the amount of the resin and the elution efficiency.

\begin{tabular}{llllc}
\hline Sample & $\begin{array}{l}\text { Volume of resin } \\
\left(\mathrm{cm}^{3}\right)\end{array}$ & $\begin{array}{l}\text { Excess } \mathrm{CO}_{2} \\
(\mathrm{~g})\end{array}$ & $\begin{array}{l}\text { Excess } \mathrm{CO}_{2} \\
\left(\mathrm{mg} / \mathrm{cm}^{3} \text { resin }\right)\end{array}$ & Efficiency \\
\hline $\mathrm{R} 1$ & 684 & 3.32 & 4.86 & $87 \%$ \\
$\mathrm{R} 2$ & 684 & 5.89 & 8.61 & $\sim 100 \%$ \\
\hline
\end{tabular}

${ }^{\mathrm{a}}$ Calculated elution efficiency if the efficiency of $\mathrm{R} 2$ is $\sim 100 \%$.

Comparing the carbon isotope data obtained by the reference $\mathrm{BaCO}_{3}$ precipitation method with the same data for the eluate, and considering the first values to be correct, we have determined the ${ }^{14} \mathrm{C}$ and $\delta^{13} \mathrm{C}$ for the excess $\mathrm{CO}_{2}$. In this calculation, we assumed that the carbon isotope concentrations in the eluate are the weighted average of the groundwater- and resin-borne carbonate. The carbon isotope features of the excess $\mathrm{CO}_{2}$ are $72.4 \mathrm{pMC}$ for ${ }^{14} \mathrm{C}$ and $-17 \%$ for $\delta^{13} \mathrm{C}$ (VPDB).

Based on the above assumptions, not only the specific amount and the carbon isotopic data of the excess $\mathrm{CO}_{2}$ should be known, but also the total amount of the eluate and the generated $\mathrm{CO}_{2}$, to correct the ${ }^{14} \mathrm{C}$ and $\delta^{13} \mathrm{C}$ values measured in the eluate. The general correction formula is the following:

$$
{ }^{14} \mathrm{C}_{w}=\frac{{ }^{14} \mathrm{C}_{e} \times m_{e}-{ }^{14} \mathrm{C}_{r} \times m_{r}}{m_{e}-m_{r}}
$$


where ${ }^{14} \mathrm{C}_{w}{ }^{14} \mathrm{C}_{e}$, and ${ }^{14} \mathrm{C}_{r}$ are the specific ${ }^{14} \mathrm{C}$ content of the groundwater, the $\mathrm{CO}_{2}$ from the eluate, and the excess $\mathrm{CO}_{2}$ deriving from the resin, respectively (pMC). The $m_{e}$ and $m_{r}$ are the total amount of $\mathrm{CO}_{2}$ deriving from the resin and excess $\mathrm{CO}_{2}$ deriving from the resin $(\mathrm{g})$.

The value of ${ }^{14} \mathrm{C}_{r}$ is $72.4 \mathrm{pMC}$ according to these calculations, which is the ${ }^{14} \mathrm{C}$ content of the excess $\mathrm{CO}_{2}$ from the resin. If the efficiency is not near $100 \%$ or it is highly variable, $m_{e}$ should be corrected with the elution efficiency $\left(0<\eta_{e}<1\right)$ :

$$
{ }^{14} \mathrm{C}_{w}=\frac{{ }^{14} \mathrm{C}_{e} \times \frac{m_{e}}{\eta_{e}}-420}{\frac{m_{e}}{\eta_{e}}-5.8}
$$

Using the quantity and isotopic properties of the excess $\mathrm{CO}_{2}$, we calculated the real ${ }^{14} \mathrm{C}$ activity concentration and $\delta^{13} \mathrm{C}$ value of the groundwater for the $\mathrm{R} 1$ test, without any influence of carbon from the resin. The correspondence between the corrected and the expected values reinforces our assumptions (Table 4 and Figures 4, 5).

Table 4 Correction of ${ }^{14} \mathrm{C}$ activity and the $\delta^{13} \mathrm{C}$ value in $\mathrm{R} 1$ test according to the calculated excess $\mathrm{CO}_{2}$ parameters.

\begin{tabular}{llcl}
\hline Sample R1 & Expected & Measured & Corrected \\
\hline${ }^{14} \mathrm{C}(\mathrm{pMC}) \pm 0.5 \mathrm{pMC}$ & 104.1 & 94.7 & 104.6 \\
$\delta^{13} \mathrm{C}(\% \mathrm{o}) \pm 0.2 \%$ (VPDB) & -11.04 & -12.81 & -10.97 \\
\hline
\end{tabular}

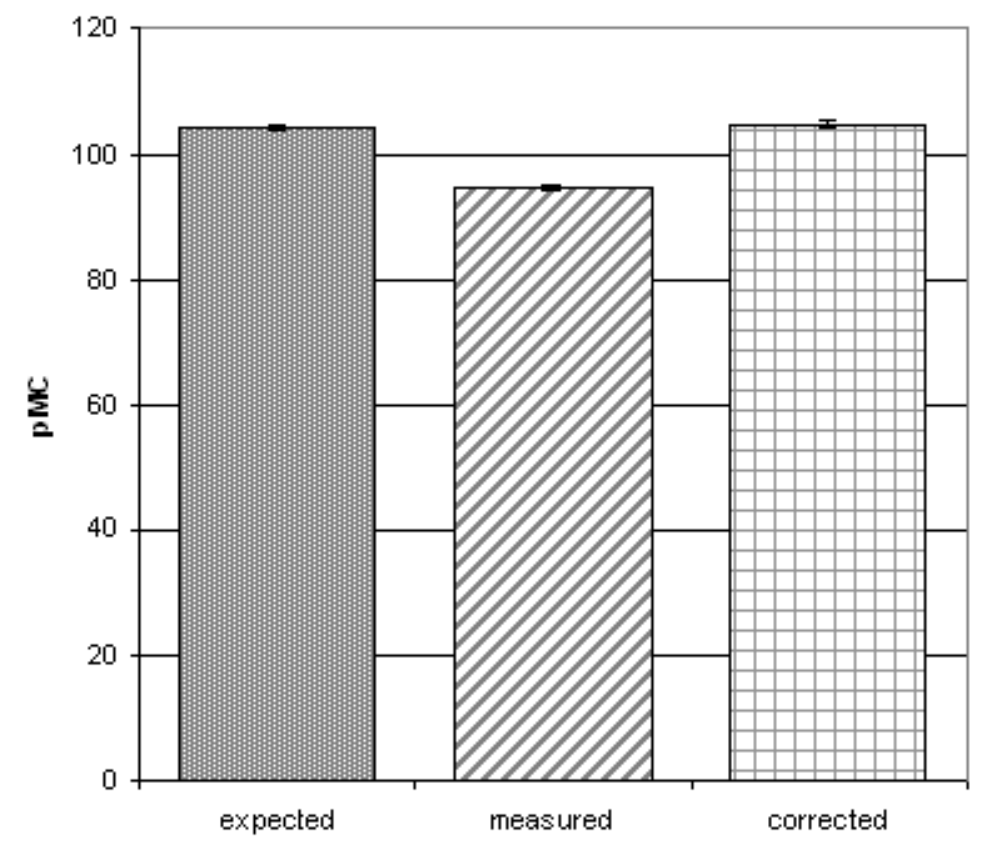

Figure 4 Correction of ${ }^{14} \mathrm{C}$ activity concentrations 


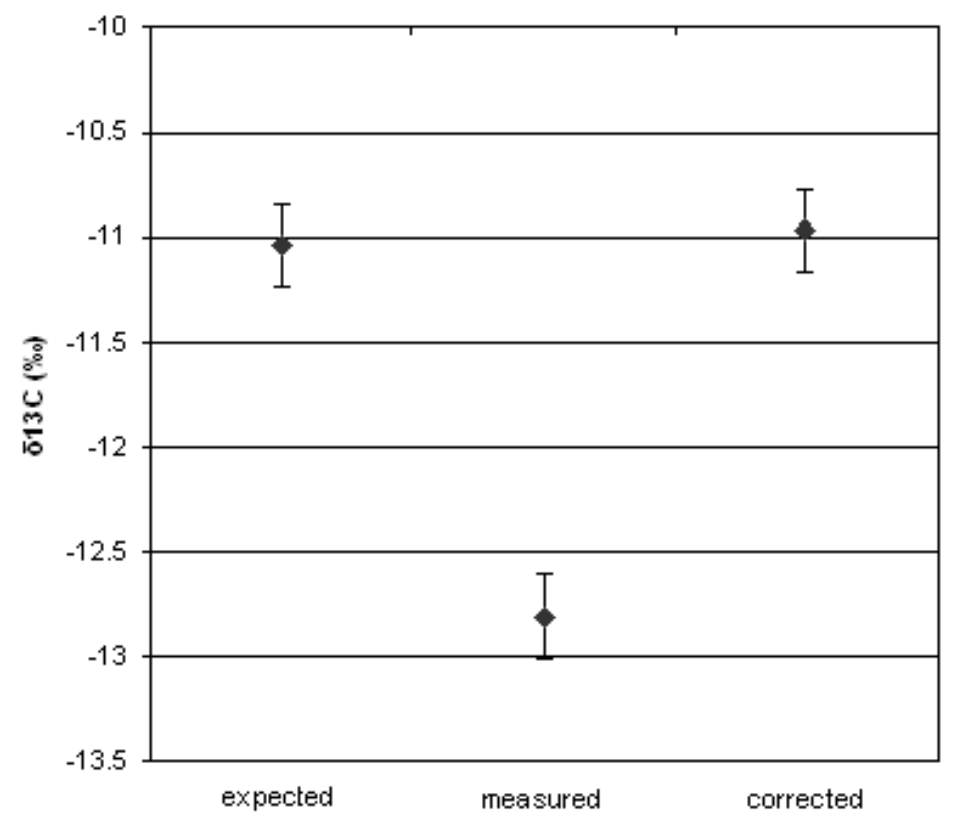

Figure 5 Correction of $\delta^{13} \mathrm{C}$ values

\section{Verification by Field Test}

The correction formula was applied for samples from the field. The value of $m_{e}$ is equivalent with the amount of the total $\mathrm{CO}_{2}$ recovered of the total amount of the eluate, if the elution efficiency is $100 \%$. Therefore, $m_{e}$ can be calculated on the basis of the amount of the $\mathrm{CO}_{2}$ generated from the recovery process.

It is difficult to measure the efficiency of the elution; therefore, either it should be verified that the efficiency is close to $100 \%$, or it should be reproducibly identical to correct with the $m_{e}$ calculated on the basis of the recovery. The reproducibility seems to be fulfilled in the course of experiments.

The $m_{r}$ is the excess $\mathrm{CO}_{2}$ deriving from the resin, which can be calculated if the volume of the resin and the excess $\mathrm{CO}_{2}$ per volume unit are known. The latter value is $8.5 \mathrm{mg}$ of $\mathrm{CO}_{2}$ per $1 \mathrm{~cm}^{3}$ of resin; thus the $m_{r}$ is $\sim 5.8 \mathrm{~g}$. The simplest formula for our sampling unit is thus:

$$
{ }^{14} \mathrm{C}_{w}=\frac{{ }^{14} \mathrm{C}_{e} \times m_{e}-420}{m_{e}-5.8}
$$

Results of the experiments were verified under field conditions. Samples were taken at the sampling area with the conventional method and by automatic sampler as well. The correction formula determined previously was applied for the results of the measurements. With the help of the correction formula, the ${ }^{14} \mathrm{C}$ activity concentrations of samples taken by the samplers correspond well with the values of the samples using the conventional $\mathrm{BaCl}_{2}$ precipitation method (Figure 6).

\section{CONCLUSION}

An automatic water sampling unit was developed for the ${ }^{14} \mathrm{C}$ measurement of groundwater. The sampler was successfully tested under controlled laboratory conditions. A correction factor should 


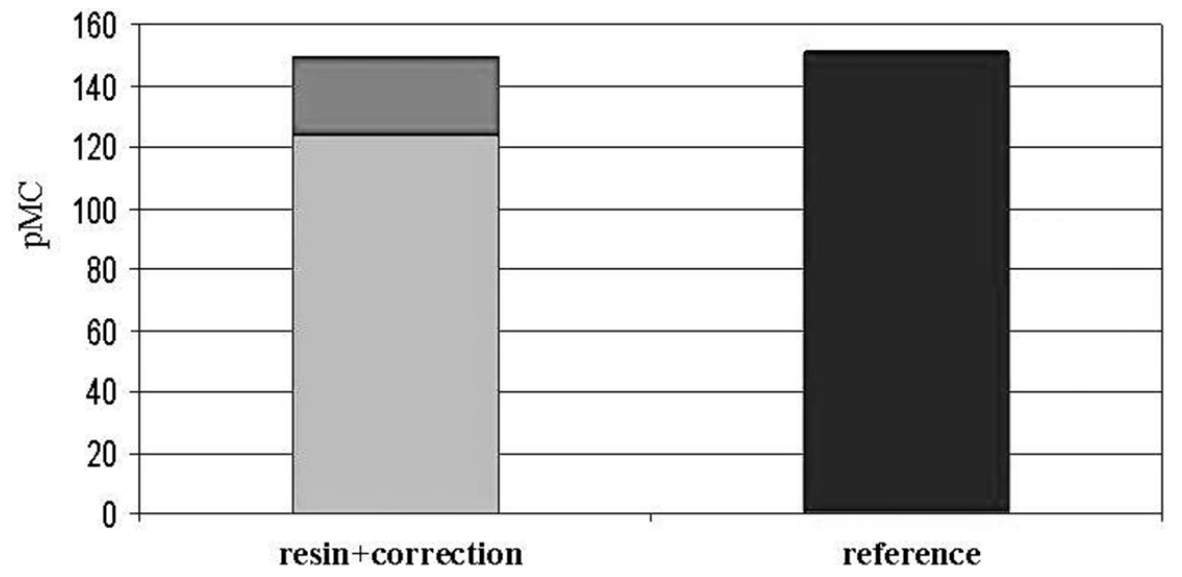

Figure $6{ }^{14} \mathrm{C}$ results of the field test

be introduced for the ${ }^{14} \mathrm{C}$ anion exchange sampling as the ${ }^{14} \mathrm{C}$ activity concentration of the groundwater measured by the ion exchange method is systematically underestimated using this system. The difference is well defined; therefore, it can be corrected. A correction formula was developed during reproducibility tests on the sampling unit, which takes the excess $\mathrm{CO}_{2}$ deriving from the resin into consideration. The ${ }^{14} \mathrm{C}$ correction factor can give a more reliable picture and direction to the development of this system and possibly for new ion-exchange resin-based sampling systems.

\section{REFERENCES}

Csongor É, Hertelendi E. 1986. Low-level counting facility for ${ }^{14} \mathrm{C}$ dating. Nuclear Instruments and Methods in Physics Research B 17(5-6):493-5.

Csongor É, Szabó I, Hertelendi E. 1982. Preparation of counting gas of proportional counters for radiocarbon dating. Radiochemical and Radioanalytical Letters 55:303-7.

de Jonge H, Rothenberg G. 2005. New device and method for flux-proportional sampling of mobile solutes in soil and groundwater. Environmental Science \& Technology 9(1):274-82.

Divine CE, Madsen LL, Andrews SD, Santangelo-Dreiling T. 2005. Passive diffusion ground water samplers at a site with heterogeneous hydrostratigraphy: pilot study results. Ground Water Monitoring and Remediation 25(1):90-9.

Eggers DE. 1976. The application of borehole geophysics to the selection and monitoring of nuclear waste disposal sites. In: Proceedings of 17th US Symposium on Rock Mechanics. Snowbird, Utah, 25-27 August 1976. US National Committee for Rock Mechanics of the National Academy of Sciences, National Research Council. p 4B-1-4B-3-7.

Granato GE, Smith KP. 1979. Robowell: an automated process for monitoring ground water quality using established sampling protocols. Ground Water Monitoring and Remediation 19(4):81-9.

Hart RJ, Spruill TB. 1988. Description and hydrogeologic evaluation of nine hazardous-waste sites in Kan-

sas, 1984-86. USGS Water Resources Investigations Report 88-4015.

Hertelendi E. 1990. Developments of methods and equipment for isotope analytical purposes and their applications [CSc thesis]. Hungarian Academy of Sciences. In Hungarian.

Hertelendi E, Csongor É, Záborszky L, Molnár J, Gál J, Györffi M, Nagy S. 1989. A counter system for highprecision ${ }^{14} \mathrm{C}$ dating. Radiocarbon 31(3):399-406.

Hazardous Waste Bureau. 2001. Use of low-flow and other non-traditional sampling techniques for RCRA compliant groundwater monitoring. Position paper of Hazardous Waste Bureau of New Mexico Environment Department, Santa Fe, New Mexico, USA.

Jones I, Lerner DN, Baines OP. 1999. Multiport sock samplers: a low-cost technology for effective multilevel ground water sampling. Ground Water Monitoring and Remediation 19(1):134-42.

Karp KE. 1993. A diffusive sampler for passive monitoring of volatile organic compounds in ground water. Ground Water 31(5):735-9.

King JA. 1993. Wastewater sampling. The National Environmental Journal 3(1):34-7.

Maucha R. 1932. Hydrochemische Metoden in der Limnologie. Binnengewasser 12. Stuttgart: Schweizerbart. $173 \mathrm{p}$.

Mulsow S, Coquery M, Dovlete C, Gastaud J, Ikeuchi Y, Pham MK, Povinec PP. 1999. Radionuclide concentrations in underground waters of Mururoa and Fanga- 
taufa atolls. Science of the Total Environment 237238(1-3):287-300.

Petruzzi NM, Silliman SE. 2006. A sampling device for collection of ground water bacteria under natural gradient flow conditions. Ground Water Monitoring and Remediation 26(1):85-91.

Ronen D, Graber ER, Laor Y. 1987. Volatile organic compounds in the saturated-unsaturated interface region of a contaminated phreatic aquifer. Vadose Zone Journal 4(2):337-44.

Spalding BP, Watson DB. 2007. Measurement of dissolved $\mathrm{H}_{2}, \mathrm{O}_{2}$, and $\mathrm{CO}_{2}$ in groundwater using passive samplers for gas chromatographic analyses. Environmental Science \& Technology 41(1):7861-7.

Stow SH, Haase CS. 1986. Subsurface disposal of liquid low-level radioactive wastes at Oak Ridge, Tennessee. In: Proceedings of the International Symposium on Subsurface Injection of Liquid Wastes. Dublin, Ohio, USA: National Water Well Association. p 656-75.

Vrba J. 1988. Groundwater quality monitoring as a tool of groundwater resources protection. In: Karst Hydrogeology and Karst Environment Protection. IAHS Publication 176, Volume 1. Wallingford: IAHS Press. p 88-97. 